\title{
Bilateral corneal wedge resection in a patient with high residual astigmatism after penetrating keratoplasty: A case report
}

\section{Resección en cuña bilateral en paciente con astigmatismo alto residual posqueratoplastia penetrante: Reporte de caso}

\author{
Cesar Hernández-Chavarría ${ }^{1 *}$, Ricardo Navarro-Saucedo ${ }^{1}$ and Héctor G. Cámara-Castillo 2,3 \\ ${ }^{1}$ Department of Ophthalmology, Hospital General Regional \# 12 Benito Juárez García, Mérida, Yucatán; ${ }^{2}$ Clínica de Mérida SA de CV, Mérida,
} Yucatán; ${ }^{3}$ Department of Ophthalmology, Hospital para Evitar la Ceguera en México, Mexico City. Mexico

\begin{abstract}
Purpose: To report a case of high astigmatism after penetrating keratoplasty treated with corneal wedge resection. Observations: We report our experience with a patient treated with corneal wedge excision for high astigmatism. A thin wedge of corneal tissue was removed from the donor-recipient interface. The wedge started on the flattest axis by keratometry and extended 20 degrees on each side; the same procedure was performed on the contralateral flat axis. The wound was closed with 10-0 nylon. We report the pre and post-operative topography. Results: The mean preoperative astigmatism by keratometry was 15 diopters (D). After wedge resection, the mean astigmatism was 1.7 D. The mean reduction in astigmatism by keratometry was of $13.3 \mathrm{D}$. Conclusion: Corneal wedge resection is a good option for high residual astigmatism after penetrating keratoplasty when the patient is not a candidate for other conservative treatments.
\end{abstract}

Key words: Cornea. Astigmatism. Keratoplasty. Grafts. Treatment. Corneal topography.

\section{Resumen}

Objetivo: Reportar un caso con astigmatismo alto residual posterior a queratoplastia penetrante tratado con resección en cuña corneal. Observaciones: Reportamos nuestra experiencia con un paciente tratado con resección en cuña por astigmatismo residual posterior a queratoplastia penetrante. Se retiró una cuña delgada de tejido corneal justo por dentro de la interface donador-receptor. La cuña se inició en el eje más plano queratométrico y se extendió 20 grados a cada lado. Se realizó el mismo procedimiento en el eje plano contralateral. La herida se cerró con nylon 10-0. Reportamos la topografía pre y posquirúrgica. Resultado: El paciente contaba con astigmatismo preoperatorio de 15 dioptrías (D) queratométricas. El astigmatismo posquirúrgico después de la resección en cuña corneal fue de 1.7 queratométricas, con reducción de 13.3 D queratométricas. Conclusiones: La resección en cuña es una opción efectiva para tratamiento de astigmatismos residuales altos posqueratoplastia penetrante cuando no es candidato a otros procedimientos conservadores.

Palabras clave: Cornea. Astigmatismo. Queratoplastía. Injertos. Tratamiento. Topografía corneal.

Correspondence:

*Cesar Hernández-Chavarría

Av. Cumbres de Maltrata, 423

Col. Narvarte Poniente Date of reception: 19-03-2018

CP 03020, Mexico City, Mexico Date of acceptance: 11-09-2018

E-mail: cesar.hernandez.chavarria@gmail.com_ DOI: 10.24875/RMOE.M20000097

Available online: 01-03-2020 Rev Mex Oftalmol (Eng). 2020;94(2):77-80 www.rmo.com.mx 2604-1731/@ 2018 Sociedad Mexicana de Oftalmología. Published by Permanyer. This is an open access article under the CC BY-NC-ND license (http://creativecommons.org/licenses/by-nc-nd/4.0/). 
Penetrating keratoplasty has been shown to be an effective treatment for a variety of corneal conditions. However, visual rehabilitation after penetrating keratoplasty remains a challenge. Good visual acuity may not be obtained due to high residual astigmatism despite a clear corneal button. The prevalence of longterm residual postoperative astigmatism is of $>5$ diopters (D) in up to $31 \%$ of the cases ${ }^{1}$. A clear corneal button with high astigmatism is interpreted by the patient as a poor result, especially when the contralateral eye has good vision or a small or no refractive error. High astigmatism can be managed with eyeglasses, contact lenses or with surgical interventions. Wedge resection involves the resection of a corneal wedge inside or outside the donor-recipient interface on the flattest axis to increase its curvature ${ }^{1}$. We report our experience with a patient treated with wedge resection for high residual astigmatism after a penetrating keratoplasty for keratoconus. We also report pre- and post-operative topographies.

\section{Case report}

A 34-year-old male patient that underwent a penetrating keratoplasty of the left eye due to keratoconus. With a regular, oblique astigmatism with a residual symmetric and orthogonal bowtie of $15 \mathrm{D}$ (Fig. 1) following suture removal 10 months after surgery. Visual acuity was counting fingers and did not improve with eyeglasses. The patient did not tolerate contact lenses. A wedge resection was performed one year after penetrating keratoplasty.

Surgical technique: A $0.75 \mathrm{~mm}$ thick wedge was removed from the cornea just inside the donor-recipient interface, according to the Troutman nomogram, which states that for a correction of 10 diopters, a wedge of $0.5 \mathrm{~mm}$ is necessary, and for each extra diopter of correction, it is required to add a $0.05 \mathrm{~mm}$ resection ${ }^{1}$. Marking of the flattest area of the cornea was performed based on the topography surface map, and a $80 \%$ corneal thickness cut was made based on ultrasound pachymetry, extending 20 degrees on each side of the $30^{\circ}$ axis (flattest meridian) at $0.75 \mathrm{~mm}$ inside the interface. Separation of the donor-recipient interface corresponding to the length of the previous incision was performed. A wedge of corneal tissue was removed and 5 single sutures of $10-0$ nylon were placed. The same procedure was performed at 180 degrees on the $210^{\circ}$ axis (opposite flattest axis). Relaxing incisions were also made at the interface at 120 (steepest axis), extending 20 degrees on each side, with $80 \%$ of

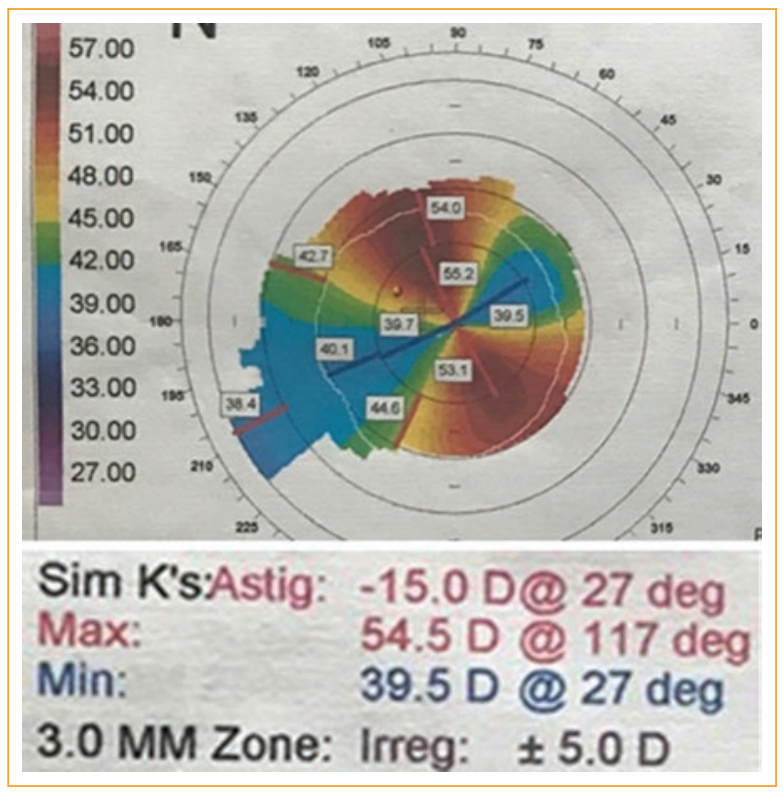

Figure 1. Pre-surgical topography.

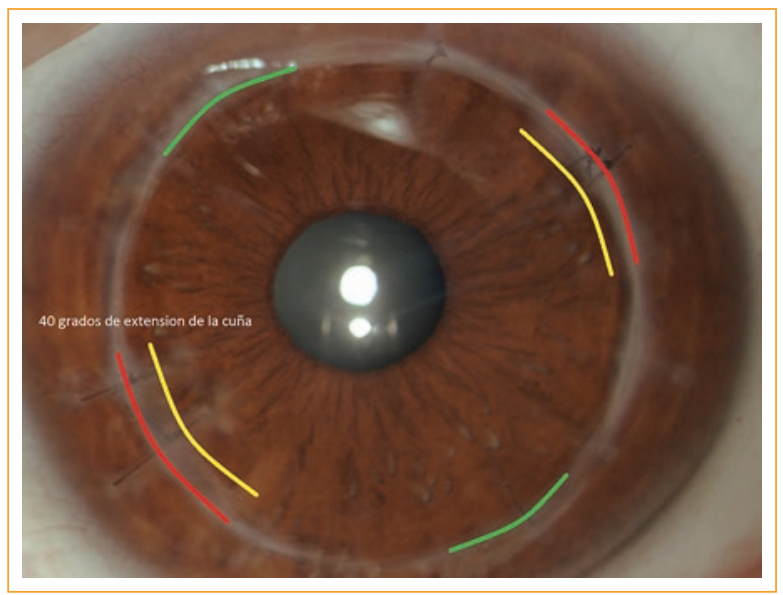

Figure 2. Red lines, incision in the interface. Yellow lines, $0.75 \mathrm{~mm}$ incisions of the corneal button interface. Green lines, relaxing incisions.

corneal thickness. Based on ultrasound pachymetry, the same procedure was performed at 180 degrees on the $300^{\circ}$ axis (opposite steepest axis).

\section{Result}

At one year of follow-up, the patient presented a clear corneal button, with a best-corrected visual acuity of $20 / 25$ with eyeglasses, a refraction of $-1.25 \times-1.50 x$ 170 and an astigmatism of $1.7 \mathrm{D}$ at 150 degrees with 3 sutures still present (Fig. 2). A reduction of $13.3 \mathrm{D}$ of astigmatism by topography was obtained (Table 1). 
Table 1. Refractive changes

\begin{tabular}{|l|c|c|}
\hline Results & Preoperative & Postoperative \\
\hline Keratometer astigmatism & $15 \mathrm{D}$ & $1.7 \mathrm{D}$ \\
\hline Visual acuity & Counting fingers & $20 / 40$ \\
\hline
\end{tabular}

\section{Discussion}

High residual astigmatism after penetrating keratoplasty remains a challenge for the surgeon, because it compromises the final visual outcome of the patient. There are several conservative treatments, which include eyeglasses, which can generate anisometropia and aniseikonia, and contact lenses, which are usually poorly tolerated. There are also surgical treatments ranging from relaxing incisions to toric intraocular lenses and laser refractive surgical techniques, such as photorefractive keratotomy and laser in situ keratomileusis, which have proven effective but have limits regarding the range of refractive error and associated complications, as graft dehiscence and flap dislocation, which have been reported in up to $9 \%$ of cases².

A large number of surgeons have implemented techniques for the reduction of corneal astigmatism with methods that increase corneal curvature, beginning with Lans in 1898. Barraquer and Muiños, in 1956, described scleral wedge resection. Techniques for flattening the cornea have also been described: Snellen, in 1869 , suggested performing anterior relaxing corneal incisions, and Sato, in 1950, described the use of posterior corneal relaxing incisions ${ }^{3}$. Troutman, in 1973, described the corneal wedge resection technique in conjunction with relaxing incisions for astigmatisms of more than $10 \mathrm{D}$, with the ability to correct 75 to $80 \%$ of these refractive errors. The principle of this technique is to increase the corneal curvature in the flattest axis by extracting a wedge and flattening the steepest axis through corneal relaxing incisions for the correction of astigmatism?

Different results have been observed in several studies. Troutman reported 10 cases, with an average astigmatic correction of 7.67 D (3-11.5 D). Krachmer, who performed corneal wedge resection without relaxing corneal incisions, obtained an average astigmatic correction of $6.75 \mathrm{D}(2.75-16.25 \mathrm{D})$ in a report of 10 cases with a follow-up of 16 months ${ }^{4}$. Hoppenreijs, et al., who reported 41 cases without relaxing incisions, achieved

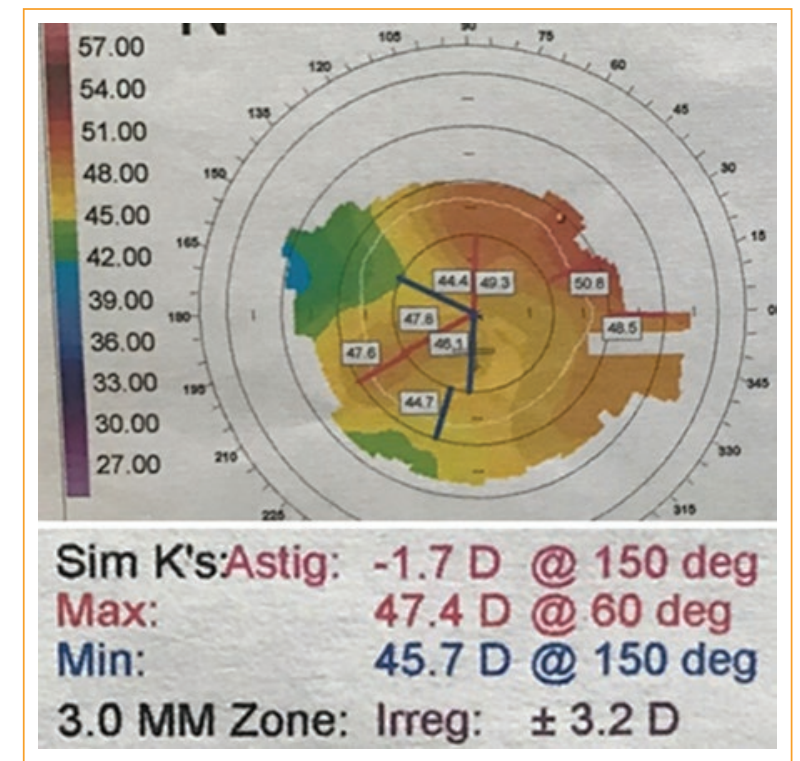

Figure 3. Post-surgical topography.

an average astigmatic correction of $8.2 \mathrm{D}(0-16.5 \mathrm{D})$, with a long-term follow-up of more than 9 years, establishing that there is a period of stability that ranges from 6 months to 3 years $^{3}$. Ezra, et al., in 2007, reported 5 cases treated with wedge resection and relaxing corneal incisions with pre- and post-surgical topography for the first time, obtaining an average astigmatic correction of $12.9 \mathrm{D}(6.3-25.4 \mathrm{D})$, with an average follow-up of 36 months $(6-96)^{2}$.

In this case report, the wedge resection technique was combined with relaxing corneal incisions to obtain a greater astigmatic correction, which was of $13.3 \mathrm{D}$, comparable to the work published by Ezra, et al., who also performed both procedures; however, our follow-up is only of 1 year and we have to consider that our patient still has three sutures (Fig. 3) that have not been removed due to low residual astigmatism; also, the sutures are in the steepest meridian, so removing them could induce a reduction in astigmatism or a change towards the other axis.

\section{Conclusion}

Wedge resection is an effective and reasonably predictable treatment for high astigmatism after penetrating keratoplasty and should be considered as a treatment option. This technique has proven useful for high residual astigmatism. For minor astigmatisms there are other less extensive and invasive techniques with good and reproducible results. 


\section{Ethical disclosures}

Protection of human and animal subjects. The authors declare that no experiments were performed on humans or animals for this study.

Confidentiality of data. The authors declare that they have followed the protocols of their work center on the publication of patient data.

Right to privacy and informed consent. The authors have obtained the written informed consent of the patients or subjects mentioned in the article. The corresponding author is in possession of this document.

\section{Conflicts of interest}

The authors declare no conflicts of interest.

\section{References}

1. Troutman RC. Corneal Wedge Resections and Relaxing Incisions for Postkeratoplasty Astigmatism Adv. Ophtalmology. Otolaryngol. 1973;77:563.

2. Ezra DG, Hay-Smith G, Mearza A, Falcon MG. Corneal Wedge Excision in the Treatment of High Astigmatism After Penetraiting Keratoplasty. Cornea. 2007;26(7):819-25.

3. Hoppenreijs VP, van Rij G, Beekhuis WH, Rijneveld WJ, Rinkel-van Driel E. Long-term results of corneal wedge resections fo the correction of high astigmatism. Documenta Ophtalmologica. 1990;75:263-73.

4. Krachmer JH, Fenzl RE. Surgical Correction of High Postkeratoplasy Astigmatism. Arch Ophthalmol. 1980;98:1400-2. 